Ann. Biol. anim. Bioch. Biophys., 1978, 18 (6), 1343-1349.

\title{
Some aspects of final follicle growth in the sow
}

\author{
par Marie-Christine DAGUET *
}

Université Pierre-et-Marie Curie, Paris VI and I.N.R.A., 78350 Jouy-en-Josas, France.

Summary. The evolution of sow follicles was studied after methallibure treatment immediately followed by PSMG. At about day 2, the follicles were separated into two populations, i. e. those ovulating and those becoming atretic. Healthy follicle diameter increased regularly between days 2 and 6, while that of atretic follicles augmented little. Before HCG injection follicular growth was accomplished by cell multiplication in the theca interna and the granulosa and by theca interna cell hypertrophy, perhaps related to smooth endoplasmic reticulum development. After HCG injection, mitotic rate decreased and granular cells hypertrophied and dissociated. Antral volume increase played a large part in final follicular growth.

\section{Introduction.}

Final follicle growth is a result of antral expansion and the multiplication of granulosa and theca cells. We are lacking information on the part played by hyperplasia, hypertrophy and follicular fluid secretion, particularly as regards the granulosa. However, quantitative data are necessary for the evaluation of gonadotropin action, follicle maturity and atresia.

To our knowledge, data on these aspects of follicle maturation are only partial and are either quantitative (sow : Corner, 1919 ; Burger, 1952 ; woman : Delforge ef al., 1972) or qualitative, i. e. mainly ultrastructural (rat : Fletcher and Everett, 1973 ; Parr, 1974 ; rabbit : Blanchette, 1966 ; Bjersing and Cajander, $1974 a, b, c$; ewe : Bjersing ef al., 1972 ; macaque : Channing and Coudert, 1976).

When using different animals to follow chronological growth, the time of the onset of the final growth phase must be determined in each case. This can be achieved by using methallibure, an inhibitor of gonadotropin secretion. After the treatment is withdrawn, follicular growth resumes and ovulation occurs 6 to 7 days later. The situation thus created is similar to that at the end of the cycle when the corpora lutea begin to regress.

* Present adress : Service du Prof. Maillet, Hôpital Fernand-Widal, 200, rue du fg St-Denis, 75010 Paris, France. 


\section{Materials and methods.}

We used 14 mature hybrid (Large White $\times$ Landrace) sows which were nulliparous or not. They were given an estrus synchronization treatment as described by Polge ef al. (1968) (fig. 1).

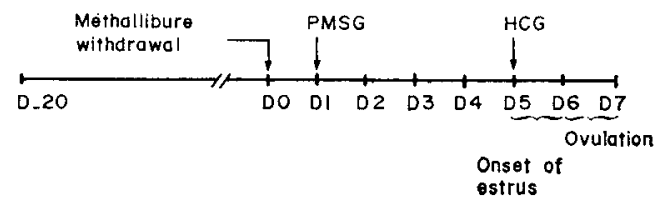

FIG. 1. - Estrus synchronization treatment (from Polge et al., 1968).

Antral follicles resumed a chronologically known growth using this treatment. An injection of 1000 IU PMSG helped to coordinate the onset in the animals. An injection of 500 IU HCG on D5 forestalled endogenous surge and also provided a second reference point in this study. Sows were checked for heat every day by a boar at $9: 00$ a.m. and 4 p.m. ; they were killed between D0 and D7. Those slaughtered at D5 were not given the HCG injection. Ovaries in toto, pieces of ovary of follicles previously isolated were treated by classical histological methods : fixation in Bouin-Hollande, paraffin embedding, $10 \mu$ serial sectioning, hematoxylin eosin staining.

The criteria for estimating Graafian follicle development were the following :

Diameter. - Using a magnification $\times 32$ and an ocular micrometer, we measured the two maximal diameters, including the theca interna. The mean diameter was computed and transformed into $\mathrm{mm}$ by referring to the millimetric scale of the micrometer. The demarcation between the theca interna and externa is very clear in the sow. The diameter of the fresh follicle was estimated under the binocular just before fixation. For a diameter of $4 \mathrm{~mm}$, it was 28 p. 100 larger than after fixation ; for an $8 \mathrm{~mm}$ diameter, it was 25 p. 100 larger. This was due to tissue retraction during histological fixation. The results (fig, 1) will be given by the first method.

For a study of diameter, the follicles were selected as follows : in toto ovary crosssections, representing the entire follicle population, were used for D0, 1 and 2 . For D0 and 1, all normal and atretic follicles having a diameter greater than $0.5 \mathrm{~mm}$ were measured and represented on figure 1 ; D2 follicles included all those having a diameter greater than $2 \mathrm{~mm}$. Cross-sections of pieces of ovary and cross-sections of isolated follicles, selected from among the largest of each ovary, were studied on D4, 5 and 6 . In both cases, all normal and atretic follicles having a diameter greater than $3 \mathrm{~mm}$ were represented on figure 1.

A follicle was considered atretic when the granulosa or theca interna cells had more than 10 pyknotic nuclei per $10 \mu \mathrm{m}$ section.

The largest diameter follicles at each stage were used to study the nucleus counts (see below).

Number of granulosa or theca interna cells per tissue volume unit. - After fixation and staining, the cell membranes were not clearly distinguished. We thus counted the nuclei contained in a volume having a cross-section equal to a square etched in an 
ocular reticulum ; the square covered almost all the field at the magnification used $(\times 800)$. The height equalled the thickness of the section, but since a nucleus could appear in two different sections, Abercrombie's correction $N \times \frac{t}{t+D}$ was used, where $N=$ number of nuclei counted, $\mathfrak{i}=$ section thickness, $D=$ mean nucleus diameter measured at a magnification $\times 800$.

The 6 fields (per section cut through the maximum diameter and per follicle) were counted every $60^{\circ}$ on the follicular surface. The mean was computed and transformed into $\mathrm{mm}^{3}$. A preliminary study had showed that 6 fields were enough to express cell numerical evolution during follicle growth.

Total number of granulosa or theca interna cells per follicle was obtained from the preceding results and by determination of granulosa or theca interna volume. These volumes were computed by estimating follicle radii and wall thicknesses. At a magnification $\times 200$, we computed the mean of 40 measurements of granulosa or theca interna thickness per follicle obtained on sections cut at maximum diameter. These 40 measurements (about one out of two fields) could thus show localized thinning of the follicular layers. This study only concerns the granulosa cells of the follicular wall and not those of the cumulus oophorus.

\section{Results.}

Follicular growth. - Figure 2 represents the evolution of healthy and atretic follicle diameters. At D0, 1 and 2 the difference in diameter between these two populations is

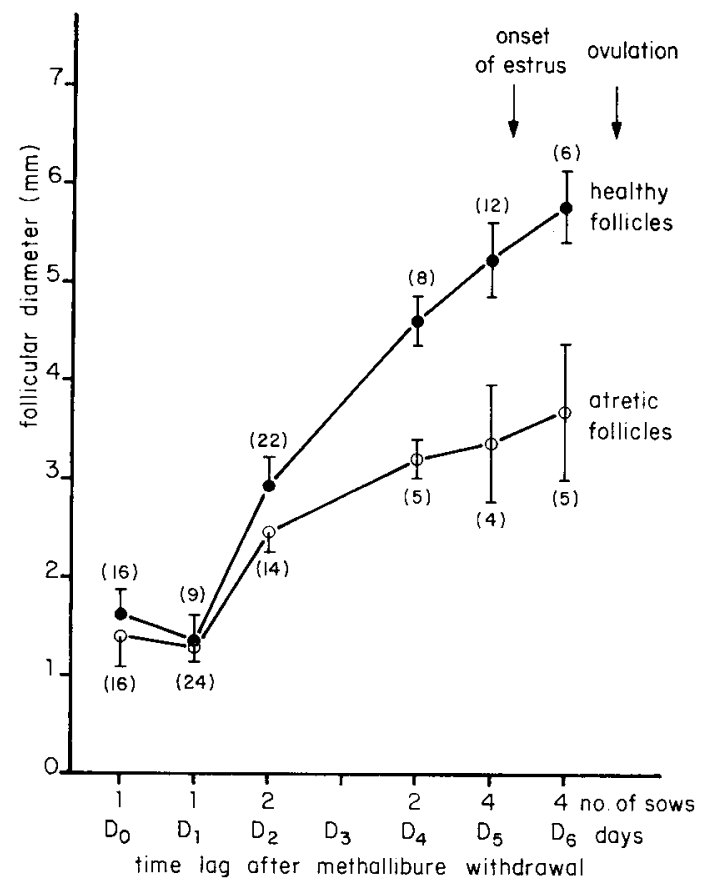

FIG. 2 - Evolution of mean follicle diameter as a function of the time lag after methallibure withdrawal. Mean confidence interval $(P=0.05)$. ( $)$ : number of follicles measured. 
not significant, while at all the other stages, healthy follicle diameter is significantly greater than that of atrefic follicles. After D2 these follicles are irreversibly separated into two populations : those ovulating and those becoming atretic. The diameter of the former increases from 1.5 to $5.2 \mathrm{~mm}$ between D0-D1 and D5, reaching $5.8 \mathrm{~mm}$ at D6, $24 \mathrm{hrs}$ after HCG injection. The size of the atretic follicles changes little, i. e. from 1.3 to $3.6 \mathrm{~mm}$ between D0-D1 and D6.

The volumes of healthy follicles, assimilated to the spheres, increases from $1.7 \mathrm{~mm}^{3}$ at D0-D1 to $101.5 \mathrm{~mm}^{3}$ at D6. In the fresh state, maximum values (corresponding to $9 \mathrm{~mm}$ diameter) reach $380 \mathrm{~mm}^{3}$ at D6.

Evolution of follicle cells.

Granulosa. - Granulosa volume increases by a factor of 4, augmenting from $2 \mathrm{~mm}^{3}$ (D2) to $4.3 \mathrm{~mm}^{3}$ (D5) and to $8.4 \mathrm{~mm}^{3}$ at D6, $24 \mathrm{hrs}$ after HCG injection. The total number of granulosa cells per follicle as related to the time lag after methallibure withdrawal (fig. 3) increases significantly $(P<0.005)$ by a factor of 3 between D2 and D6, i. e. from 2.1 millions (D2) to 4.7 millions (D5), and reaches 6.3 millions at D6.

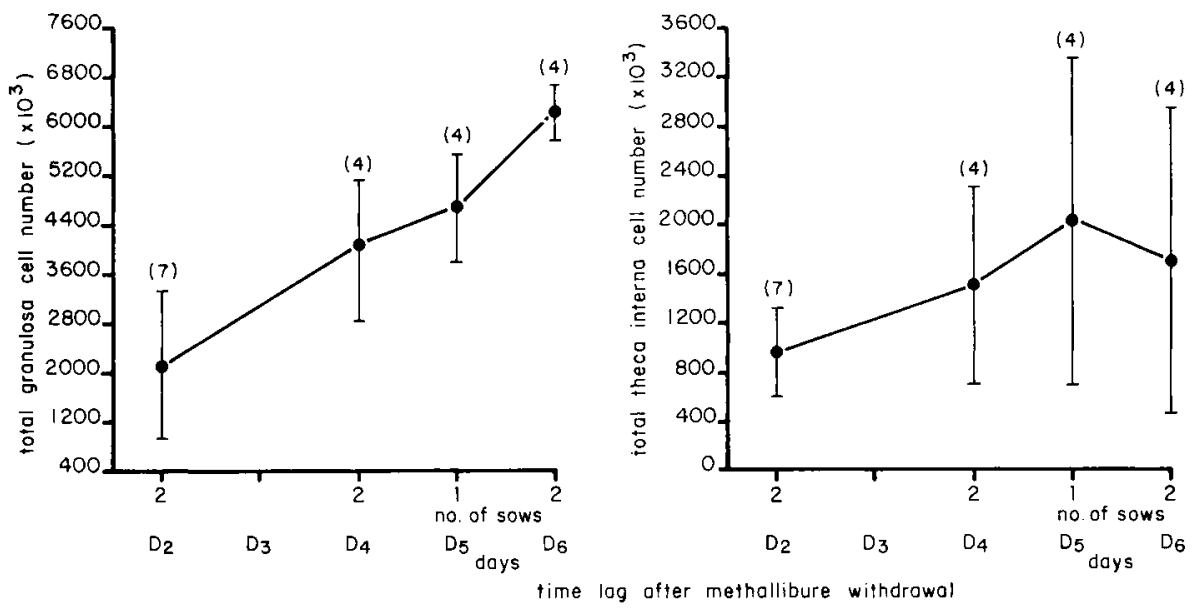

FIG. 3. - Evolution of the total mean number of granulosa and theca inferna cells as a function of the time log after methallibure withdrawal. Mean confidence internal $(P=0.05) .(\quad)$ : number of follicles analyzed.

The number of cells estimated per $\mathrm{mm}^{3}$ of tissue (fig. 4) seems stable until D5 and then shows a significant decrease at D6 $(P<0.01)$ of 22 p. 100 (from about 950000 to 710000 ).

As Bjersing (1967) showed in sow, the demarcation between the avascular granulosa and the theca interna is clear; granulosa cells adjacent to the basal lamina are columnar. This pattern disappears after HCG injection.

Theca inferna. - The volume of theca interna increases from $1.3 \mathrm{~mm}^{3}$ (D2) to $3.8 \mathrm{~mm}^{3}$ (D5) and reaches $4 \mathrm{~mm}^{3}$ at D6 (growth factor of 3.07). The estimation of the total number of cells per follicle shows wide individual variation. On the average, it doubles between D2 and 6 (fig. 3). 
The number of cells per $\mathrm{mm}^{3}$ decreases significantly $(P<0.005)$ by 41 p. 100 after D2, then remains stable ; it diminishes from 770000 to 450000 (fig. 4).

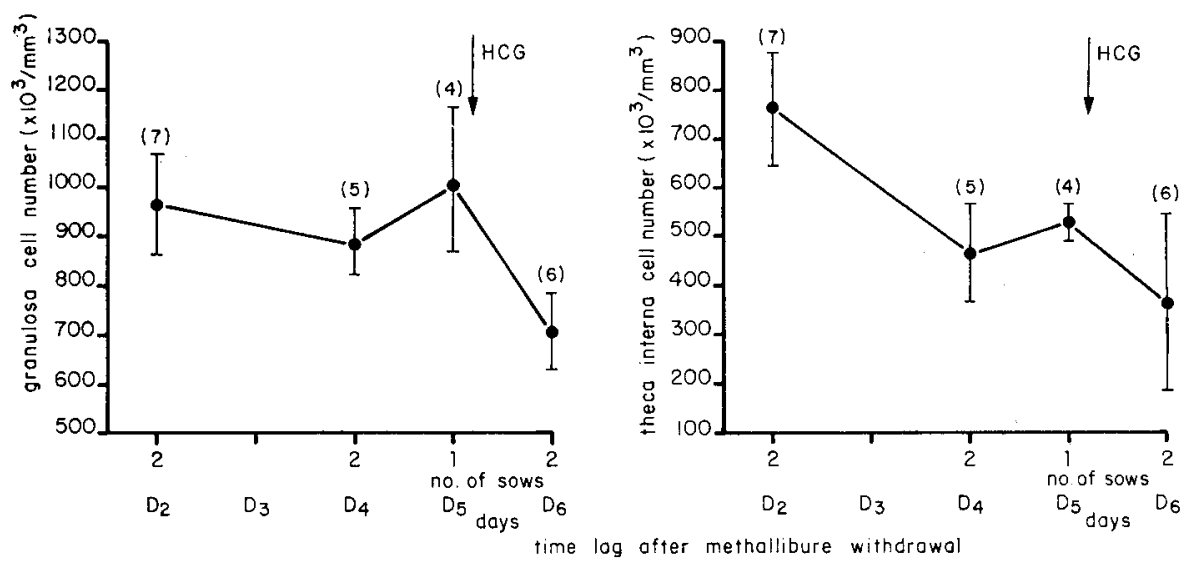

FIG. 4. - Evolution of the mean number of granulosa and theca interna cells per $\mathrm{mm}^{3}$ of tissue as a function of the time lag after methallibure withdrawal. Mean confidence interval $(P=0.05) .()$ : number of follicles analysed.

From D2 to 5 the increase of granulosa volume represents 3.85 p. 100 of the increase in follicle volume during that same period ; theca interna increase represents 4.18 p. 100. After HCG injection, from D5 to 6, granulosa augmentation is 14.6 p. 100 of the increase in follicle volume for the same period; that of the theca interna is $0.71 \mathrm{p}$. 100. This increment is thus only a small part of follicular growth, and antral volume augmentation appears considerable.

Preovulatory follicle growth may be interpreted as follows :

- Before HCG injection between D2 and 5, growth may be due to granulosa multiplication (the number doubles in 3 days), moderate multiplication of theca interna cells, an increase in theca interna cell volume and/or in intercellular space, equivalent to about 40 p. 100 of the volume of the cells measured at D2.

- After HCG injection at D6, final follicular growth results from a 20 p. 100 increase in granulosa volume due to 3 factors : augmentation of cell volume, increase of intercellular space and cell multiplication. However, the number of mitoses in the granulosa and theca interna is less after HCG injection (reduced division or the longer time necessary for division). This confirms the data of Corner (1919) in sow and of Delforge ef al. (1972) in woman. In this study the total number of granulosa cells per follicle increases linearly, indicating decreased mitotic activity which is always expressed by an exponential curve.

\section{Discussion.}

The separation of the follicles into two populations (those ovulating and those becoming atretic) after D2 may explain why Hunter, Cook and Baker (1976) obtained 
superovulation in sow only after HCG injection on day 17 of the cycle (onset of the follicular phase), while the same injection on days 18,19 or 20 did not significantly increase mean ovulation rate. These results confirm that after D2 (equivalent to D17 of the normal cycle), the number of preovulatory follicles is reduced and that HCG injection on D17 better stimulates follicles to ovulate than on the following days when the number is reduced by atresia regulating normal ovulation rate.

The evolution of follicular cells may explain final follicle growth as follows :

Before HCG injection. - Cell multiplication in the theca interna and the granulosa plays an important role in follicular growth at this stage. The reduction in the number of theca interna cells per volume unit after D2 may be explained by an increase in cell volume corresponding to an increase in steroidogenic activity. Using radioimmunological assay, Rombauts (personal communication) has shown an augmentation of estradiol-17 $\beta$ level on D4 in the follicular fluid of sows used for our study.

Contrary to this result, Bjersing ef al. (1972) studying ewe, Bjersing and Cajander (1974b) in rabbit and Parr (1974) in rat observed an increase in theca interna cell volume concomitant with development of the smooth endoplasmic reticulum only several hours after HCG injection.

After HCG injection. - The reduction in the number of granulosa cells per volume unit after HCG injection could be due to increased cell volume. In woman, mean granulosa cell volume increases from $800 \mu \mathrm{m}^{3} 24 \mathrm{hrs}$ before LH surge to $1600 \mu \mathrm{m}^{3}$ during the surge and attains $3000 \mu \mathrm{m}^{3} 36 \mathrm{hrs}$ later (Delforge et al., 1972). This increase in volume might indicate the onset of luteinization by a change in the secretory function of follicular fluid-secreting cells which become steroidogenic. The number of mitochondries increases and there is extensive development of the smooth endoplasmic reticulum (sow : Szöllösi, personal communication ; woman : Delforge et al., 1972 ; rabbit : Blanchette, 1966 ; Bjersing and Cajander, 1974a ; rat : Fletcher and Everett, 1973).

A progesterone peak appeared about D5.5 in the follicular fluid at the sows we used; this peak reached $600 \mathrm{ng} / \mathrm{ml}$ (Rombauts, personal communication). The reduced number of granulosa cells per volume unit after HCG injection would also be due to cell dissociation (increase of intercellular spaces) which would facilitate follicle expansion. Szöllösi (personal communication) notes the separation of interdigitation sites between the cells of the granulosa in sow. Bjersing and Cajander (1974a) observed progressive decrease in gap junctions up to ovulation.

Cell dissociation may be facilitated by increased plasmin activity augmenting in vitro the elasticity of follicular walls (Beers, 1975) and activating procollagenase (Beers, Strickland and Reich, 1975). Collagenase would enable the follicle walls to stretch without excessive pressure (Espey, 1974).

It should be noted that the PMSG dose used (1 $000 \mathrm{IU})$ is not strong enough to trigger a large superovulation. However, it could affect follicular cell dynamics. These results are therefore limited since the spontaneous estrous cycle of control sows was not studied. 
Acknowledgements. - I wish to thank Dr. C. Thibault and Dr. D. Szöllösi for advice, A. Solari for help in the statistical analysis of results, J. Surel for technical assistance and A. Daifuku for the preparation of this manuscript.

\section{References}

BEERS W. H., 1975. Follicular plasminogen and plasminogen activator and the effect of plasmin on ovarian follicle wall. Cell, 6, 379-385.

BEERS W. H., STRICKLAND S., REICH E., 1975. Ovarian plasminogen activator : relationships to ovulation and hormonal regulation. Cell, 6, 387-394.

BJERSING L., 1967. On the ultrastructure of follicles and isolated follicular granulosa cells of porcine ovary. Z. Zellforsch., 82, 173-186.

BJERSING L., CAJANDER S., 1974a. Ultrastructure of membrana granulosa of rabbit graafian follicles prior to induced ovulation. Cell Tiss. Res., 153, 1-14.

BJERSING L., CAJANDER S., 1974b. Ultrastructure of theca interna and the inner vascular network surrounding rabbit Graafian follicles prior to induced ovulation. Cell Tiss. Res., 153, 31-44.

BJERSING L., CAJANDER S., 1974c. Ultrastructure of tunica albuginea and theca externa of rabbit Graafian follicle prior to indiced ovulation. Cell Tiss. Res., 153, 15-30.

BJERSING L., HAY M. F., KANN G., MOOR R. M., NAFTOLIN F., SCARAMUZZI R. J., SHORT R. V., YOUNGLAI E. V., 1972. Changes in gonadotropins, ovarian steroids and follicular morphology in sheep at cestrus. J. Endocr., 52, 465-479.

BLANCHETTE E. J., 1966. Ovarian steroid cells. I. - Differentiation of the lutein cell from the granulosa follicle cell during the preovulatory stage and under the influence of exogenous gonadotropins. J. Cell Biol., 31, 501-516.

BURGER J. F., 1952. Sex physiology of pigs. Onderstepoort J. vet. Res., 22, Suppl. 2.

CHANNING C. P., COUDERT S. P., 1976. Contribution of granulosa cells and follicular fluid to ovarian estrogen secretion in the Rhesus monkey in vivo. Endocrinology, 98, 590-597.

CORNER G. W., 1919. On the origin of the corpus luteum of the sow from both granulosa and theca interna. Am. J. Anat., 26, 117-183.

DELFORGE J. P., THOMAS K., ROUX F., CARNEIRO de SIQUEIRA J., FERIN J., 1972. Tissue relationships between granulosa cells growth discharge in human. I-A morphometric analysis. Fertil. Steril., 23, 1-11.

ESPEY L. L., 1974. Ovarian proteolytic enzymes and ovulation. Biol. Reprod., 10, 216-235.

FLETCHER W. H., EVERETT J. W., 1973. Ultrastructural reorganization of rat granulosa cells on the day of proestrus. Anat. Rec., 175, 320.

HUNTER R. H. F., COOK B., BAKER T. G., 1976. Dissociation of response to injected gonadotropin between the graafian follicle and oocyte in pigs. Nature, 260, 156-157.

PARR E. L., 1974. Histological examination of the rat ovarian follicle wall prior to ovulation. Biol. Reprod., 11, 483-503.

POLGE C., DAY B. N., GROVES T. W., 1968. Synchronization of ovulation and artificial insemination in pigs. Vet. Rec., 83, 136-142. 